\section{Reports}

1481

Parasite facilitates plant species coexistence in a coastal wetland • BRENDA J. GREWELL

1489

Flooding impacts on responses of a riparian consumer to cross ecosystem subsidies • MICHEUE $J$ GREENWOOD AND ANGUS R. MCINTOSH

1497

Pulses of dead periodical cicadas increase herbivory of American bellflowers - LOUIE H. YANG

1503

Resource availability and the abundance on an N-based defense in Australian tropical rain forests - ReBECCA E. MiLleER AND IAN E. WOODROW

\section{Concepts and Synthesis}

1510

Consequences of dominance: a review of evenness effects on local and regional ecosystem Processes - HELMUT HILEBRAD, DANUTA M. BENNET,

\section{Articles}

1521

Spatial decoupling of facilitation and competiSpatial decoupling of facilitation and competi-
tion at the origin of gapped vegetation patterns - NICOLAS BARBIER, PIERRE COUTERON, RENÉ LEFEVER, VINCENT DEBLAUWE, AND OLIVIER LEJEUNE

1532

Season- and herbivore-dependent competition and facilitation in a semiarid savanna $-K A R I E$. VEBLEN

1541

Separating habitat invasibility by alien plants from the actual level of invasion - MILAN CHYTRY, VOJTĚCH JAROŠIK, PETR PYŠEK, ONDŘEJ HÁJEK, ILONA KNOLLOVÁ, LUBOMIIR TICHÝ, AND JIŘI DANIHELKA
1554

Photosynthetic resource-use efficiency and demo- TRAVIS E HUXMAN GREG BARRON GAFFORD plants KATHARINE L GEPST AMY L ANGERT ANIA P. TYLR D. LAWRENCE VENABLE

Mutualists and antagonists mediate frequencydependent selection on floral display

- per tORÄNG, JOHAN EHRLÉN. AND JON ÁGREN

1573

Temporal dynamics in a pollination network - JENS M. OLESEN, JORDI BASCOMPTE, HEIDI ELBERLING, AND PEDRO JORDANO

1583

Mimics and magnets: the importance of color and ecological facilitation in floral deception - cRaIG I. PETER AND STEVEN D. JOHNSON

1596

Bridging the generation gap in plants: pollination parental fecundity, and offspring demography

1605

Increasing enemy biodiversity strengthens herbivore suppression on two plant species - CORY $S$. STRAUB AND WILIAM E. SNYDER

1616

Genetic variation in defense chemistry in wild cabbages affects herbivores and their endoparasioids - RIETA GOLS, R. WAGENAAR, TIBOR BUKOVINSZKY, NICOLE M. VAN DAM, MARCEL DICKE, JAMES M. BULLOCK, AND JEFFREY A. HARVEY

1627

Life-history trade-offs influence disease in changing climates: strategies of an amphibian pathogen - DOUGLAS C. WOODHAMS, ROSS A. ALFORD, CHERYL J. BRIGGS, MEGAN JOHNSON, AND LOUISE A. ROLLINS-SMITH

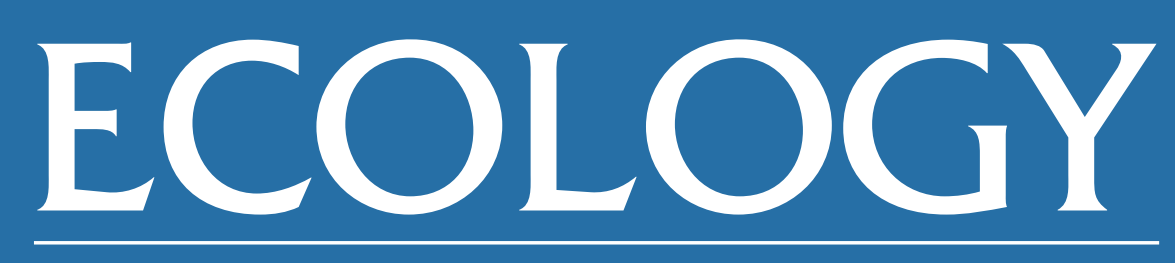

A PUBLICATION OF THE ECOLOGICAL SOCIETY OF AMERICA

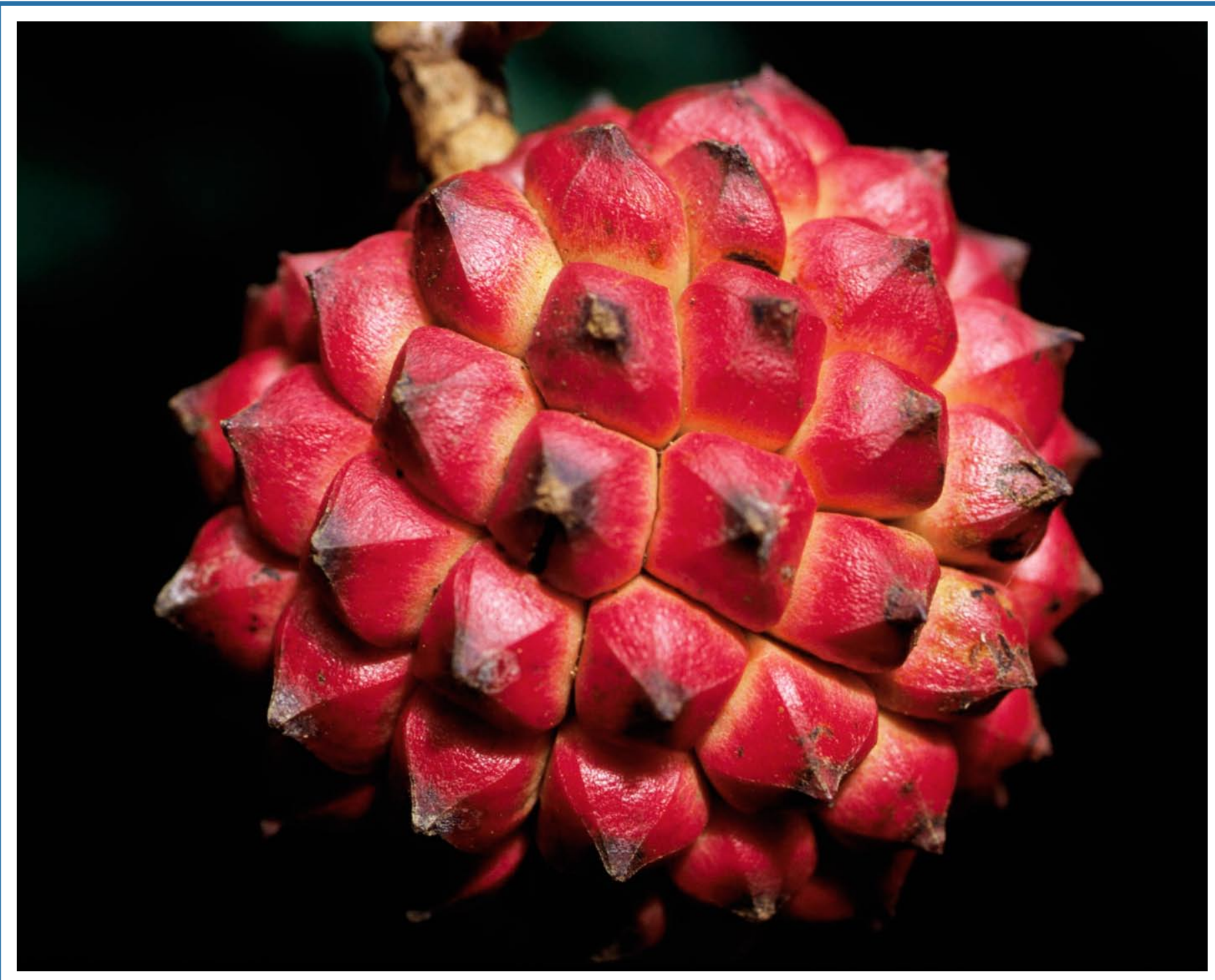

Reports

Parasite facilitates plant species coexistence in a coastal wetland Concepts \& Synthesis

Consequences of dominance: a review of evenness effects on local and regional ecosystem processes

\section{Articles}

Spatial decoupling of facilitation and competition at the origin of gapped vegetation patterns Tree recruitment in an empty forest 


\title{
TREE RECRUITMENT IN AN EMPTY FOREST
}

\author{
John Terborgh, ${ }^{1,8}$ Gabriela Nuñez-Iturri, ${ }^{2}$ Nigel C. A. Pitman, ${ }^{1}$ Fernando H. Cornejo Valverde, ${ }^{3}$ \\ Patricia Alvarez, ${ }^{4}$ Varun Swamy, ${ }^{5}$ Elizabeth G. Pringle, ${ }^{6}$ and C. E. Timothy Paine ${ }^{7}$ \\ ${ }^{1}$ Duke University Center for Tropical Conservation, Nicholas School of the Environment and Earth Sciences, P.O. Box 90318, \\ Durham, North Carolina 27708 USA \\ ${ }^{2}$ Department of Biological Sciences MC 066, University of Illinois, Chicago, Illinois 60607 USA \\ ${ }^{3}$ Botanical Research Institute of Texas, 509 Pecan Street, Fort Worth, Texas 76102 USA \\ ${ }^{4}$ Department of Plant Biology and Pathology, Rutgers University, 59 Dudley Road, New Brunswick, New Jersey 08901 USA \\ ${ }^{5}$ Nicholas School of the Environment and Earth Sciences, Duke University, Durham, North Carolina 27708 USA \\ ${ }^{6}$ Department of Biological Sciences, Stanford University, Stanford, California 94305 USA \\ ${ }^{7}$ Department of Biological Sciences, Louisiana State University, Baton Rouge, Louisiana 70803 USA
}

\begin{abstract}
To assess how the decimation of large vertebrates by hunting alters recruitment processes in a tropical forest, we compared the sapling cohorts of two structurally and compositionally similar forests in the Rio Manu floodplain in southeastern Peru. Large vertebrates were severely depleted at one site, Boca Manu (BM), whereas the other, Cocha Cashu Biological Station (CC), supported an intact fauna. At both sites we sampled small $(\geq 1$ $\mathrm{m}$ tall, $<1 \mathrm{~cm} \mathrm{dbh})$ and large $(\geq 1 \mathrm{~cm}$ and $<10 \mathrm{~cm} \mathrm{dbh})$ saplings in the central portion of 4-ha plots within which all trees $\geq 10 \mathrm{~cm}$ dbh were mapped and identified. This design ensured that all conspecific adults within at least $50 \mathrm{~m}(\mathrm{BM})$ or $55 \mathrm{~m}$ (CC) of any sapling would have known locations.

We used the Janzen-Connell model to make five predictions about the sapling cohorts at BM with respect to CC: (1) reduced overall sapling recruitment, (2) increased recruitment of species dispersed by abiotic means, (3) altered relative abundances of species, (4) prominence of large-seeded species among those showing depressed recruitment, and (5) little or no tendency for saplings to cluster closer to adults at BM. Our results affirmed each of these predictions.

Interpreted at face value, the evidence suggests that few species are demographically stable at $\mathrm{BM}$ and that up to $28 \%$ are increasing and $72 \%$ decreasing. Loss of dispersal function allows species dispersed abiotically and by small birds and mammals to substitute for those dispersed by large birds and mammals. Although we regard these conclusions as preliminary, over the long run, the observed type of directional change in tree composition is likely to result in biodiversity loss and negative feedbacks on both the animal and plant communities. Our results suggest that the best, and perhaps only, way to prevent compositional change and probable loss of diversity in tropical tree communities is to prohibit hunting.
\end{abstract}

Key words: Amazon; empty forest; Janzen-Connell hypothesis; Peru; seed dispersal; seed predation; tree recruitment.

\section{INTRODUCTION}

Redford's (1992) prescient paper warning of the conservation implications of the "empty forest" has inspired a burgeoning interest in better understanding the roles played by animals in tree recruitment (see also Emmons 1989). Animals pollinate flowers, disperse seeds, consume seeds, and eat the foliage of seedlings and established plants. These roles are especially prominent in tropical forests where animals interact with plants at every stage of the life cycle. Recent research has demonstrated that tropical forests depleted of large vertebrates experience reduced dispersal, altered patterns of tree recruitment, shifts in the relative

Manuscript received 20 March 2007; revised 14 September 2007; accepted 25 September 2007; final version received 17 October 2007. Corresponding Editor: R. W. Ruess.

8.E-mail:manu@duke.edu abundance of species, and various types of functional compensation (e.g., increased invertebrate seed predation in response to reduced vertebrate seed predation; Dirzo and Miranda 1991, Asquith et al. 1999, Wright et al. 2000, Cordeiro and Howe 2001, Wright 2003, Wyatt and Silman 2004, Wang et al. 2006, Andresen and Laurance 2007).

With a notable exception in Wright et al. (2007a), most such studies have focused on one or a few species of large-seeded, animal-dispersed trees, leaving open the question of whether reduction of dispersal function impacts whole tree communities or only a limited subset of species (see Plate 1). The question is an important one because, increasingly, the world's tropical forests are under assault by artisanal hunters and the bushmeat trade (Robinson et al. 1999, O'Brien and Kinnaird 2000, Peres 2000, Fa et al. 2002, Peres and Lake 2003, Wright 


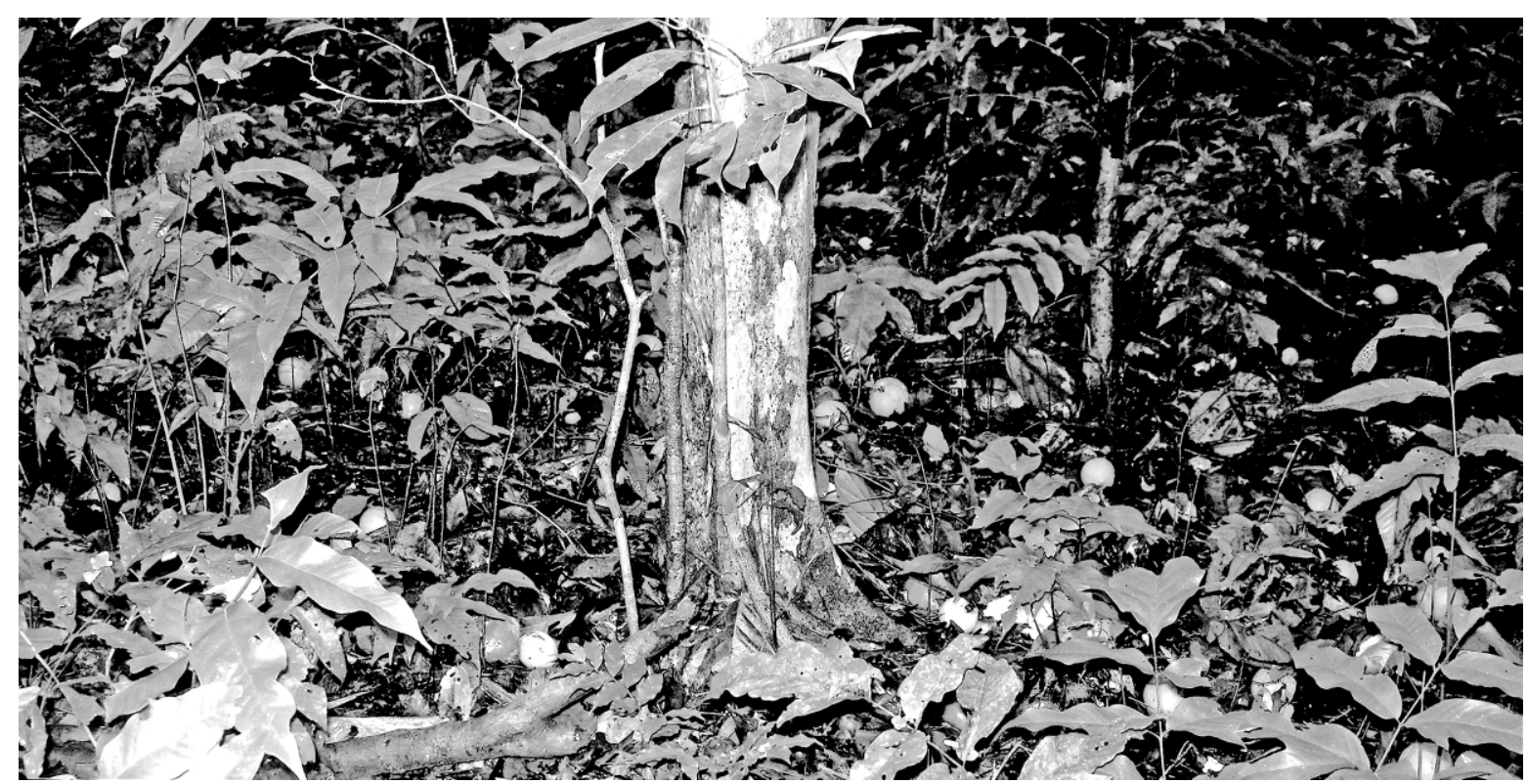

Plate 1. Tree of Eugenia sp. surrounded by fallen, undispersed fruits. Photo credit: P. Alvarez.

et al. 2007b). Unhunted tracts are dwindling in size and number at a precipitous rate (Peres and Palacios 2007).

How will eliminating large vertebrates affect the perpetuation of tree diversity in tropical forests? Here we seek a provisional answer to this question by comparing sapling cohorts in relation to adult tree stands at two otherwise similar sites, one unhunted and one that has been exposed to market hunting for $\geq 30$ years. Our results suggest that that the loss of large vertebrates is a perturbation that reverberates through the entire tree community.

\section{Theory: the Janzen-Connell hypothesis}

A priori predictions can be derived from the theory proposed more than 35 years ago by Janzen (1970) and Connell (1971). Janzen and Connell (J-C) conceived the theory after puzzling over the paradox that established saplings are often scarce near reproductive conspecifics, despite abundant seedfall under and around mature adults. J-C proposed that reproductive adult trees serve as attractors for pollinators, seed dispersers, seed predators, seedling herbivores, and as reservoirs of host-specific invertebrates and pathogens (Fig. 1). The balance between positive (pollination, seed dispersal) and negative consequences (seed predation, herbivory, pathology) of attracting animals and pathogens will determine when, where, and how successfully a tree is able to reproduce.

The crux of the $\mathrm{J}-\mathrm{C}$ hypothesis is that pathogens and insect pests specialized to a particular species will operate more intensely close to than farther away from reproductive adult trees. The theory is formalized by two curves: one representing a stylized seed shadow and the other the distance-dependent impact of enemies (termed the "escape" curve). The shape and height of the seed shadow specify the potential for recruitment, whereas the escape curve describes the realization of that potential, i.e., the fraction of seeds surviving to germination and beyond. The product of the two curves generates a "population recruitment curve" which predicts the distribution of new recruits around the parent tree.

\section{Predictions}

The J-C hypothesis makes predictions at the level of individual species and, by extension, the whole tree community. Recruitment is postulated to be skewed away from reproductive individuals, creating a zone of reduced conspecific recruitment in the vicinity of adults that is open to colonization by the saplings of other species. Despite many attempts to test the $\mathrm{J}-\mathrm{C}$ model, there is little solid knowledge of how wide the zone of reduced recruitment may be for different tree species and whether and how much the strength of negative distance effects may vary between species (Howe et al. 1985, Hubbell and Foster 1990, Condit et al. 1992, Terborgh et al. 2002). In principle, the stronger the suppression of recruitment around adults, the greater the number of species that can coexist in the tree community (Hubbell 1980).

The basic $\mathrm{J}-\mathrm{C}$ model is readily modified to anticipate the effects of various types of distortions in the animal community (Terborgh and Nuñez-Iturri 2006). Decimation of seed dispersers by overhunting, for example, would result in lowering the tail of the seed shadow, so that a larger proportion of the seed crop would fall within the zone of suppressed recruitment around adults and thus be doomed to fail (Fig. 1). If the escape curve remained unchanged, the prediction would be for 


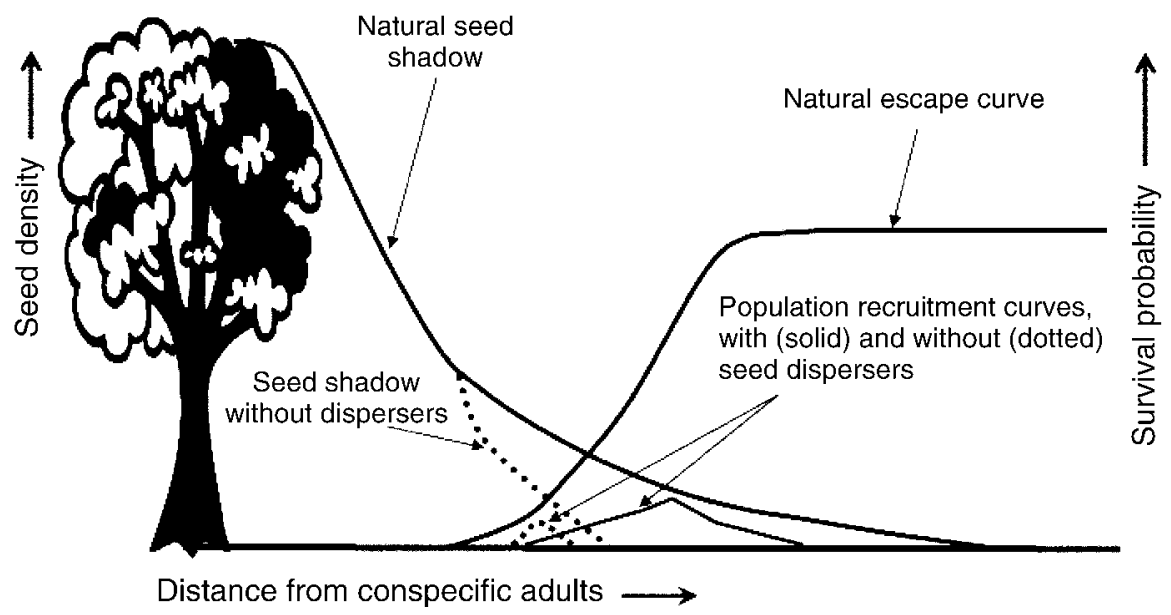

FIG. 1. Janzen-Connell model (Janzen 1970, Connell 1971) with modifications leading to predictions described in the text. The $x$-axis represents distance from the focal tree, and the $y$-axis (relative scale) represents the density of seeds falling to the ground (seed shadow) or the proportion of seeds surviving to maturity (escape curves).

reduced sapling recruitment with little or no change in the spatial distribution of recruits. However, if hunting were selectively directed at seed predators and/or herbivores, the effect would be to elevate the escape curve while leaving the seed shadow unchanged. The expected consequences would be to shift recruitment closer to adults and to increase recruitment overall. Finally, a pattern of hunting that indiscriminately decimated seed dispersers, seed predators, and herbivores would result in simultaneously lowering the seed shadow and elevating the escape curve. The prediction in this case would be a shift in recruitment closer to adults. Overall recruitment might increase or decrease, depending on the relative degrees to which the dispersal and escape curves deviated from their natural shapes.

There is mounting evidence that hunting may have greater consequences for dispersal than for the escape process (Wright 2003, Wyatt and Silman 2004). Dispersal of large seeds is primarily carried out by large birds and mammals, among which primates predominate in continental forests (Andresen 1999, Peres and van Roosmalen 2002, Poulsen et al. 2002, Russo 2003). Canopy-dwelling birds and primates are easy targets for hunters because the upper strata of tropical forests are more open than vegetation near the ground. Thus, large primates are typically among the first animals to be depleted in hunted forests (Peres 2000). In contrast, seed predation and seedling herbivory are both carried out by a wide range vertebrates and invertebrates, opening the potential for compensatory responses to missing larger guild members (Asquith et al. 1997, 2005, Peres and Dolman 2000, Wright 2003).

We therefore make the assumption that hunting results in reduced dispersal with little or no change in the escape process, recognizing that the assumption may only be an approximation. Using this assumption, we make five predictions for tree recruitment in an "empty forest" based on the J-C model. (1) Overhunting should lead to truncated seed-shadow curves of species dispersed by large birds and mammals, resulting in lower overall recruitment of saplings. (2) Under reduced dispersal, sapling cohorts should contain a higher proportion of stems of species dispersed by small birds and mammals and by abiotic means, and a reduced proportion of stems of species dependent on large birds and mammals. (3) As implied by predictions 1 and 2, we anticipate major shifts in the relative abundances of species, as suggested by altered composition of sapling cohorts. (4) Large-seeded tree species dispersed primarily by larger birds and mammals should predominate among those showing reduced recruitment. (5) Under the assumption that the escape curve is unaltered by depletion of large dispersers, sapling distributions of affected species are not expected to shift toward conspecific adults.

We tested these predictions by comparing sapling cohorts to adult tree stands in two closely matched Amazonian floodplain forests. One is a typical "empty forest" with a 32-year history of market hunting, and the other supports an intact fauna.

\section{Methods \\ Study sites}

The "empty" forest was located near the village of Boca Manu (12 $\left.16^{\prime} \mathrm{S}, 70^{\circ} 54^{\prime} \mathrm{W}\right)$ across an oxbow lake from the Piro indigenous community of Isla de los Valles. The intact site was at the Cocha Cashu Biological Station located deep within the Manu National Park $\left(11^{\circ} 54^{\prime} \mathrm{S}, 71^{\circ} 22^{\prime} \mathrm{W}\right)$. The stands are $90 \mathrm{~km}$ apart and were matched for edaphic qualities, successional age, structure, and species composition. Both are situated on silty entisols in the floodplain of the Manu River in southeastern Peru and are successionally mature, as suggested both by species composition and the presence of individuals $\geq 1 \mathrm{~m} \mathrm{dbh}$ of late successional species (Terborgh et al. 1996). 
Intensive hunting in the forest at BM began in 19721973 when the Cities Service Corporation (now Citgo) established a petroleum exploration camp nearby. At the climax of the exploration project, there were 1100 workers living in an improvised town across the Madre de Dios River from Boca Manu (J. Terborgh, personal observation). The large worker population generated a market for bushmeat that spurred members of the indigenous Piro community to become commercial hunters. Intensive hunting continued until 1976 when Cities Service concluded its operation and withdrew from the region. Less intensive commercial hunting has continued to the present to supply the town of Boca Manu and nearby indigenous communities. Populations of many large birds and mammals have been severely depleted within a several kilometer radius around. Neither site had experienced commercial logging at the time of our research, although four Attalea palms had recently been harvested for thatch at the $\mathrm{BM}$ site (representing 0.003 of the adult trees in the plot).

The elapsed time between the initiation of commercial hunting at BM and our measurements was 32 years. Given a tree turnover rate of $1.7 \%$ per year (the rate at CC; Terborgh and Gentry 1990), $\sim 42 \%$ of the adult trees in the stands at both sites would have died and been replaced during the interval. However, most trees recruiting into the adult size class over the 32 years would already have been present in the stand as saplings, so the adult tree stand present at BM in 2004 can be presumed to consist predominately of old adults plus recruits that originated as seedlings prior to the initiation of intensive hunting. The presumption of little or no influence of hunting will be less true for large saplings $(\geq 1 \mathrm{~cm}$ and $<10 \mathrm{~cm} \mathrm{dbh})$ and least for small saplings (those $\geq 1 \mathrm{~m}$ tall and $<1 \mathrm{~cm} \mathrm{dbh}$ ). Just how long saplings typically remain in the understory before recruiting as adults is a matter of debate and, in any case, is sure to vary greatly both within and between species (Hubbell 2004). Thus, it is not practical to specify even an approximate age for the two sapling cohorts. Instead, we make the much more conservative assumption that small saplings, on average, arose as seedlings more recently than large saplings. Thus, we expect the influence of intensive hunting on recruitment dynamics to be greatest in the small sapling cohort and least in the adult stand at BM.

Transect counts were carried out at $\mathrm{CC}$ and $\mathrm{BM}$ to document faunal differences. Censuses were performed using a standardized line-transect method (Peres 1999). At each site a 4-km transect was sampled for 13-16 days both by day and by night, and during both dry (2003) and wet (2004) seasons. Diurnal censuses began at 06:00 hours and nocturnal censuses at 18:00 hours and progressed at a mean speed of $1 \mathrm{~km} / \mathrm{h}$. We recorded the number of mammals and large birds detected along the census transect with estimates of the perpendicular distance from the target or the center of the group (gregarious animals) to the transect line. We used
DISTANCE software to calculate animal densities (software available online). ${ }^{9}$ Total distance walked was $220 \mathrm{~km}$ at CC and $208 \mathrm{~km}$ at BM. We cut new transect trails to avoid pre-existing hunting trails. Completed transects were left undisturbed for at least four days prior to the initiation of censusing to allow animals time to resume their normal ranging habits.

To compare sapling recruitment in relation to adult tree stands, we first established tree plots measuring 200 $\times 200 \mathrm{~m}$ (4 ha) at both sites. Within these plots, all trees $\geq 10 \mathrm{~cm}$ dbh were mapped, numbered, measured, and identified. The central portions of the tree plots $(0.81$ ha at $\mathrm{CC}, 1.0$ ha at BM) were then subsampled for two classes of saplings (small, $\geq 1 \mathrm{~m}$ tall and $<1 \mathrm{~cm}$ dbh; large, $\geq 1 \mathrm{~cm} \mathrm{dbh}$ and $<10 \mathrm{~cm} \mathrm{dbh}$ ). The inclusion of a broad strip of mapped trees around the areas sampled for saplings ensured that the conspecific adult nearest to each sapling would have a known location up to a minimum of $55 \mathrm{~m}$ (CC) or $50 \mathrm{~m}$ (BM; Terborgh et al. 2002). Within each plot, saplings and adults were mapped in a common coordinate system, permitting straightforward calculation of the distance of each sapling to the nearest conspecific adult.

The identification of all trees and saplings was made at the time they were mapped and tagged and later checked by J. Terborgh and/or N. Pitman. When an identification was in doubt, we collected a voucher, brought it to camp, and discussed it with other team members. If that failed to resolve the identification, the voucher was retained and a digital photo was made of the specimen. Vouchers are in storage at CC and digital photos are available on request. Unidentified stems represent $<5 \%$ of the total in any size class at each site.

A possible confounding effect of light gaps on sapling densities was investigated by sampling both sapling plots for light availability using an ad hoc method similar to that employed by Welden et al. (1991). An observer walked evenly spaced lines in the plots and recorded the presence of foliage in vertically superimposed zones at grid intersections spaced $7.5 \mathrm{~m}$ apart at $\mathrm{CC}$ and $5 \mathrm{~m}$ apart at BM. The data for $\mathrm{CC}$ were interpolated to bring the spacing intervals into conformity with the $5 \times 5 \mathrm{~m}$ cells employed at BM. The two grids were imported into ArcGIS to generate maps of canopy height encompassing the sapling plots at both sites. The proportions of cells having canopy heights of 0 to $<5 \mathrm{~m}, \geq 5$ to $\leq 20 \mathrm{~m}$, and $>20 \mathrm{~m}$ at the two sites were then compared by $G$ test.

Tree species were assigned to one of nine dispersal modes (autochorous, bird, bat, large primate, small arboreal mammal, terrestrial mammal, unknown, water, wind). Assignments were based on observations accumulated at CC over 30 years of research on primates, birds, bats, and terrestrial mammals (Terborgh 1983, Foster and Janson 1985, Romo 1997). Many of these

\footnotetext{
$9\langle$ h t t p : / / w w w.ruwpa.s t-and.ac.uk/distance/ distancedownload.html $\rangle$
} 
observations are documented in unpublished dissertations. When we were uncertain of the primary disperser group for a given species, we consulted published sources, particularly van Roosmalen (1985), Gentry (1993), and especially Stevenson et al. (2000).

For analyses, we reduced the number of dispersal categories to seven in order to conform to the requirements of chi-square tests (combining the autochorous, water, and unknown modes into a category of "other"). Expected values were calculated as the number of stems in each category observed at BM multiplied by the proportion of stems in the respective categories at $\mathrm{CC}$ divided by the total number of stems at BM. To permit direct comparisons between sapling and adult stands, sapling cohorts were filtered to exclude three categories of species: (1) those maturing at $<10 \mathrm{~cm} \mathrm{dbh}$, (2) species not represented in the adult stands of either site, and (3) palms.

The demographic status of a tree population can be assessed via the ratio of saplings to adults (Condit et al. 1998). Interspecifically, these ratios vary from $<1$ to $\gg 1$, but intraspecifically the number of saplings per adult reflects the biology of the species and is presumed to be relatively consistent across sites. However, overall sapling numbers were lower at BM by nearly a factor of two. To control for sapling density, we adjusted the number of saplings of each species at BM by multiplying it by 1.91 (small saplings) or 1.66 (large saplings), the factors by which sapling density was greater at CC. Using adjusted sapling numbers for BM, we then assumed that intraspecific sapling/adult ratios would be the same at both sites. Thus, our null hypothesis for species in common to the two sites was that

$$
\frac{\text { adjusted number of saplings/adult at BM }}{\text { number of saplings/adult at } \mathrm{CC}}=1.0 \text {. }
$$

Inclusion in the analysis required one or more individuals in each of four cohorts: saplings and adults at BM and saplings and adults at CC. Deviations from the expected value of parity spanned a range of $>10^{3}$, so we used logarithms of the ratios for further analysis. Deviations were analyzed in relation to seed dry mass (Prediction 4) in two ways: first, in a nonparametric correlation (Spearman's rho) with 56 species, and second, by comparing (via $t$ test) the seed masses of the 10 species representing the most extreme departures (both positive and negative) from the expected ratio of 1.0. Seed dry masses were obtained from a seed collection maintained at $\mathrm{CC}$ and an associated database.

Prediction 5 was that sapling distributions should not shift toward conspecific adults under the assumption of unaltered escape curves. We examined the spatial distribution of saplings in relation to adults by using a simple formula that describes the expected mean nearest neighbor distance of points randomly arrayed in a plane:

$$
D_{\exp }=\frac{1}{2} \sqrt{\text { density }}
$$

TABLE 1. Densities of vertebrate seed dispersers and seed predators at Cocha Cashu Biological Station (CC) and Boca

\begin{tabular}{|c|c|c|}
\hline \multirow[b]{2}{*}{ Functional group } & \multicolumn{2}{|c|}{ No. $/ \mathrm{km}^{2}$} \\
\hline & $\mathrm{CC}$ & $\mathrm{BM}$ \\
\hline \multicolumn{3}{|l|}{ Arboreal seed dispersers, diurnal } \\
\hline $\begin{array}{l}\text { Primates, large (spider monkeys, howler } \\
\text { monkeys) }\end{array}$ & 67.2 & 0.0 \\
\hline Primates, mid-sized (capuchins) & 98.9 & 8 \\
\hline $\begin{array}{l}\text { Primates, small (titis, squirrel monkeys, } \\
\text { tamarins) }\end{array}$ & 70.4 & 86 \\
\hline Birds, large (guans, trumpeter) & 31.6 & 2 \\
\hline \multicolumn{3}{|l|}{ Arboreal seed dispersers, nocturnal } \\
\hline Mid-sized (kinkajous, olingos, night monkeys) & 20.7 & 33. \\
\hline \multicolumn{3}{|l|}{ Terrestrial seed predators, diurnal } \\
\hline Large (collared and white-lipped pecca & 98.2 & 16 \\
\hline Mid-sized (agouti, acouchi) & 17.4 & 10 \\
\hline Small (squirrels) & 41.1 & 35.3 \\
\hline
\end{tabular}
Manu (BM), Peru.

where $D_{\text {exp }}$ is the expected mean distance between randomly arrayed saplings and conspecific adults based on the density of adults $(\geq 10 \mathrm{~cm} \mathrm{dbh})$ in the stand. We define $D_{\text {obs }}$ as the observed mean distance between saplings and the nearest conspecific adult. If saplings are scattered at random with respect to conspecific adults, $D_{\text {exp }}=D_{\text {obs }}$, but if saplings are skewed toward adults,

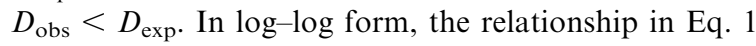
plots as a straight line. Residuals below the line indicate species with saplings clumped closer to adults than if arrayed at random; residuals located above the line indicate hyperdispersion.

\section{RESUlTS}

Communities of vertebrate dispersers and seed predators.

Densities of large birds and mammals at the two sites were estimated via transect counts (Table 1). Large primates were so scarce at BM as to be undetectable. Medium-sized primates were depleted by $>90 \%$, as were large frugivorous birds, whereas the density of small primates was similar at the two sites. There was no difference in the density of frugivorous nocturnal arboreal mammals. Large terrestrial seed predators (peccaries) were reduced by $>80 \%$ at $\mathrm{BM}$ and mid-sized species by $\sim 40 \%$; the density of small diurnal seed predators (squirrels) was roughly equivalent at the two sites. It is important to note that small nocturnal rodents $(<0.5 \mathrm{~kg})$ comprise a significant component of the seed predator community in Neotropical forests (Adler 1995) and that these were not censused. Given that local hunters do not hunt at night and in any case do not take mammals weighing $<1.0 \mathrm{~kg}$, small nocturnal rodents were presumably unaffected by hunting at BM.

\section{Similarity of the two forests}

The tree stands of the two forests were similar with respect to density of adult trees $(\geq 10 \mathrm{~cm} \mathrm{dbh})$, basal area, species richness, and species composition (Table 2). 
TABLE 2. Structural and compositional characteristics of adult tree stands in 4-ha plots at Cocha Cashu Biological Station (CC) and Boca Manu (BM), Peru.

\begin{tabular}{lrr}
\hline \hline \multicolumn{1}{c}{ Stand value } & CC & BM \\
\hline No. adult trees $/ 4$ ha & 2313 & 2347 \\
Basal area $/ 4$ ha $\left(\mathrm{m}^{2}\right)$ & 132 & 134 \\
Approximate no. species $/ 4$ ha & 269 & 252 \\
No. shared species & 183 & 183 \\
\hline
\end{tabular}

Note: Adult trees are arbitrarily defined as those possessing stems $\geq 10 \mathrm{~cm} \mathrm{dbh}$.

Similarity in species composition is indicated by the large proportion of shared species (70\%) and high correlation of species abundances between the stands (Spearman $r$ (pairwise) $=0.78, P<0.0001$ )

Seventeen of the top-ranked 25 species at CC were included within the 25 top ranks at BM (Table 3 ). Of the total of 33 species listed, 21 are dispersed by nonflying mammals $(64 \%), 14$ of these by large primates or large terrestrial mammals ( $42 \%$ of the total), and only two (6\%) by abiotic means (wind).

The representation of dispersal modes by species in the adult tree stands was similar (Fig. 2a). The number of species in the seven categories used in the analysis did not differ significantly between $\mathrm{BM}$ and $\mathrm{CC}$ (chi-square $=3.5, \mathrm{df}=6, P=0.74)$. However, a significant difference emerged when numbers of stems were used instead of species (chi-square $=155, \mathrm{df}=6, P<0.001$ ). Post hoc tests indicated significant differences in two categories: bat and terrestrial mammal. In both instances, the differences are attributable to a single species in each category: Otoba parvifolia (Myristicaceae), a bat-dispersed species that was the most abundant tree at BM (third at CC), and Pouteria ephedrantha (Sapotaceae), a species dispersed by terrestrial mammals (agoutis, acouchis) that was more common at CC.

\section{Prediction 1: sapling densities}

Prediction 1 was that overall sapling densities would be lower at Boca Manu. The expectation was upheld for both large saplings (density $40 \%$ lower at BM, $P<0.01$ ) and small saplings (density $48 \%$ lower at $\mathrm{BM}, P<0.01$ ) by $t$ test, using subplots as replicates (Table 4).

It is well known that high sapling densities are associated with light gaps (Hubbell et al. 1999), so the higher sapling densities encountered at CC could potentially reflect a greater prevalence of light gaps at that site. We investigated this possibility by recording the presence of foliage in three vertically superimposed

TABle 3. Species included in the 25 top ranks of the adult tree stands at CC and BM and their respective dispersal modes.

\begin{tabular}{|c|c|c|c|c|c|c|}
\hline \multirow[b]{2}{*}{ Species } & \multirow[b]{2}{*}{ Family } & \multicolumn{2}{|l|}{$\mathrm{CC}$} & \multicolumn{2}{|l|}{$\mathrm{BM}$} & \multirow[b]{2}{*}{ Dispersal mode } \\
\hline & & No. individuals & Rank & No. individuals & Rank & \\
\hline Quararibea wittii & Bombacaceae & 169 & 1 & 83 & 5 & SAM \\
\hline Astrocaryum murumuru & Arecaceae & 151 & 2 & 120 & 3 & TM \\
\hline Otoba parvifolia & Myristicaceae & 120 & 3 & 307 & 1 & $\mathrm{Bt}$ \\
\hline Scheelea cephalotes & Arecaceae & 97 & 4 & 93 & 4 & SAM \\
\hline Iriartea deltoidea & Arecaceae & 93 & 5 & 183 & 2 & $\mathrm{Bt}$ \\
\hline Theobroma cacao & Sterculiaceae & 75 & 6 & 65 & 8 & LP \\
\hline Guarea macrophylla & Meliaceae & 71 & 7 & 62 & 9 & $\mathrm{Bd}$ \\
\hline Pouteria ephedrantha & Sapotaceae & 51 & 8 & 7 & 64 & TM \\
\hline Malmea diclina & Annonaceae & 50 & 9 & 17 & 24 & LP \\
\hline Pseudolmedia laevis & Moraceae & 50 & 10 & 74 & 6 & SAM \\
\hline Lunania parviflora & Flacourtiaceae & 38 & 11 & 23 & 17 & $\mathrm{Bd}$ \\
\hline Duguetia quitarensis & Annonaceae & 34 & 12 & 0 & $\mathrm{n} / \mathrm{a}$ & SAM \\
\hline Ruizodendron ovale & Annonaceae & 34 & 13 & 10 & 50 & LP \\
\hline Lonchocarpus spiciflorus & Fabaceae & 32 & 14 & 21 & 20 & $\mathrm{~W}$ \\
\hline Trichilia poeppigii & Meliaceae & 29 & 15 & 15 & 33 & $\mathrm{Bt}$ \\
\hline Drypetes amazonica & Euphorbiaceae & 27 & 16 & 37 & 12 & LP \\
\hline Unonopsis mathewsii & Annonaceae & 26 & 17 & 18 & 23 & SAM \\
\hline Sapium marmieri & Euphorbiaceae & 24 & 18 & 17 & 25 & $\mathrm{Bd}$ \\
\hline Matisia cordata & Bombacaceae & 23 & 19 & 57 & 10 & LP \\
\hline Jacaratia digitata & Caricaceae & 22 & 20 & 15 & 31 & LP \\
\hline Caraipa densifolia & Clusiaceae & 21 & 21 & 16 & 28 & $\mathrm{~W}$ \\
\hline Leonia glycycarpa & Violaceae & 21 & 22 & 69 & 7 & SAM \\
\hline Poulsenia armata & Moraceae & 20 & 23 & 0 & $\mathrm{n} / \mathrm{a}$ & $\mathrm{Bt}$ \\
\hline Batocarpus amazonica & Moraceae & 18 & 24 & 14 & 34 & LP \\
\hline Celtis schippii & Ulmaceae & 18 & 25 & 34 & 13 & $\mathrm{Bd}$ \\
\hline Sorocea pileata & Moraceae & 15 & 34 & 20 & 21 & LP \\
\hline Virola calophylla & Myristicaceae & 14 & 35 & 20 & 22 & LP \\
\hline Brosimum alicastrum & Moraceae & 11 & 40 & 23 & 16 & LP \\
\hline Iryanthera olacoides & Myristicaceae & 11 & 42 & 54 & 11 & SAM \\
\hline Pouteria torta & Sapotaceae & 11 & 43 & 22 & 19 & LP \\
\hline Pouteria caimito & Sapotaceae & 4 & 99 & 26 & 15 & LP \\
\hline Chrysochlamys ulei & Clusiaceae & 3 & 112 & 32 & 14 & $\mathrm{Bd}$ \\
\hline Pleurothyrium "stilt roots" & Lauraceae & 0 & $\mathrm{n} / \mathrm{a}$ & 23 & 18 & $\mathrm{Bd}$ \\
\hline
\end{tabular}

Notes: Abbreviations for dispersal mode are: $\mathrm{Bd}=$ bird; $\mathrm{Bt}=$ bat; $\mathrm{LP}=$ large primate; $\mathrm{SAM}=$ small arboreal mammal; $\mathrm{TM}=$ terrestrial mammal; $\mathrm{W}=$ wind. Three species of palms are listed that were excluded from the analysis of sapling cohorts. 

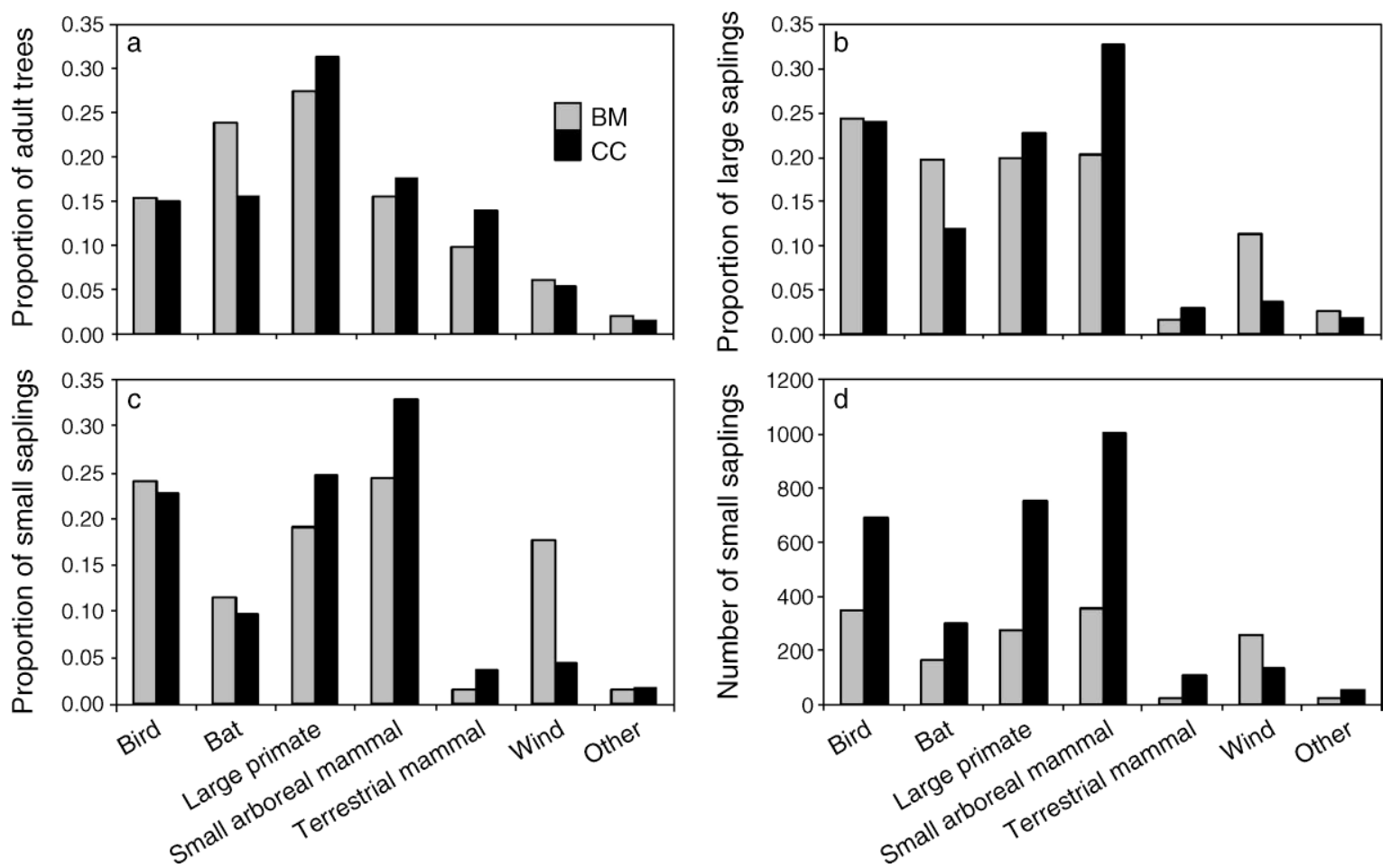

FIG. 2. Dispersal syndromes as represented in various size cohorts of stems at Cocha Cashu Biological Station (CC) and Boca Manu (BM), Peru: (a) proportions of adult trees $(\geq 10 \mathrm{~cm} \mathrm{dbh),} \mathrm{(b)} \mathrm{proportions} \mathrm{of} \mathrm{large} \mathrm{saplings,} \mathrm{(c)} \mathrm{proportions} \mathrm{of} \mathrm{small} \mathrm{saplings,}$ (d) number of small saplings.

zones ( 0 to $<5, \geq 5$ to $<20$, and $\geq 20 \mathrm{~m}$ ) at the intersections of grid lines through the respective sapling plots (see Methods). The proportions of grid cells in each canopy height category did not differ $\left(G_{\text {adj2 }}=0.018, P=\right.$ 0.99 ), effectively ruling out differences in prevalence of gaps as a factor contributing to the difference in sapling density at the two sites.

\section{Prediction 2: dispersal modes}

The second prediction was that sapling cohorts at BM should contain a higher proportion of stems of abiotically dispersed species (autochorous + wind) and a reduced proportion of stems of biotically dispersed species (all zoochorous modes). "Other" constituted a small third category. The expectation was strongly upheld for both small and large saplings (chi-square = $434, \mathrm{df}=2, P<0.001$ and chi-square $=292, \mathrm{df}=2, P<$ 0.001 , respectively).

A comparison of Fig. 2b, c with Fig. 2a reveals that the dispersal mode spectrum of large and small saplings at Boca Manu diverges progressively from that of the adult tree stand. This is reflected in corresponding chisquare values of 155,593 , and 655 for BM vs. CC comparisons of stem numbers of adults and large and small saplings, respectively. Despite these large differences based on stem counts, we found no significant differences in the distribution of species among the categories.
Whereas the principal differences between the adult tree stands were in the bat and terrestrial mammal classes, the greatest differences between sapling cohorts were deficiencies at $\mathrm{BM}$ in the arboreal mammal category and excesses in the wind category. These, respectively, accounted for $77 \%$ and $97 \%$ (wind alone, $89 \%$ ) of the chi-square values for contrasts between the large and small stem cohorts at BM and CC. Comparing the actual numbers of saplings in each category (instead of adjusted numbers) reveals that the small sapling cohort at BM was deficient in all animal dispersed groups (Fig. 2d); only in the wind-dispersed category were there more saplings at BM than at $\mathrm{CC}$.

\section{Prediction 3: sapling to adult ratios}

The third prediction was that distortions in the tree recruitment process at $\mathrm{BM}$ would be reflected in changes

TABle 4. Comparison of stem densities at Cocha Cashu Biological Station (CC) and Boca Manu (BM), Peru.

\begin{tabular}{lrrr}
\hline \hline & \multicolumn{2}{c}{ No. stems/ha } & \\
\cline { 2 - 3 } \multicolumn{1}{c}{ Stem category } & CC & BM & BM/CC (\%) \\
\hline No. adult trees $(>10 \mathrm{~cm} \mathrm{dbh})$ & 576 & 587 & 102 \\
No. large saplings $(\geq 1 \mathrm{~cm}$ dbh) & 5129 & 3087 & 60 \\
No. small saplings $(\geq 1 \mathrm{~m}$ tall, & & & \\
$\quad<1 \mathrm{~cm}$ dbh) & 5360 & 2807 & 52 \\
Total no. large and small saplings & 10489 & 5894 & 56 \\
\hline
\end{tabular}



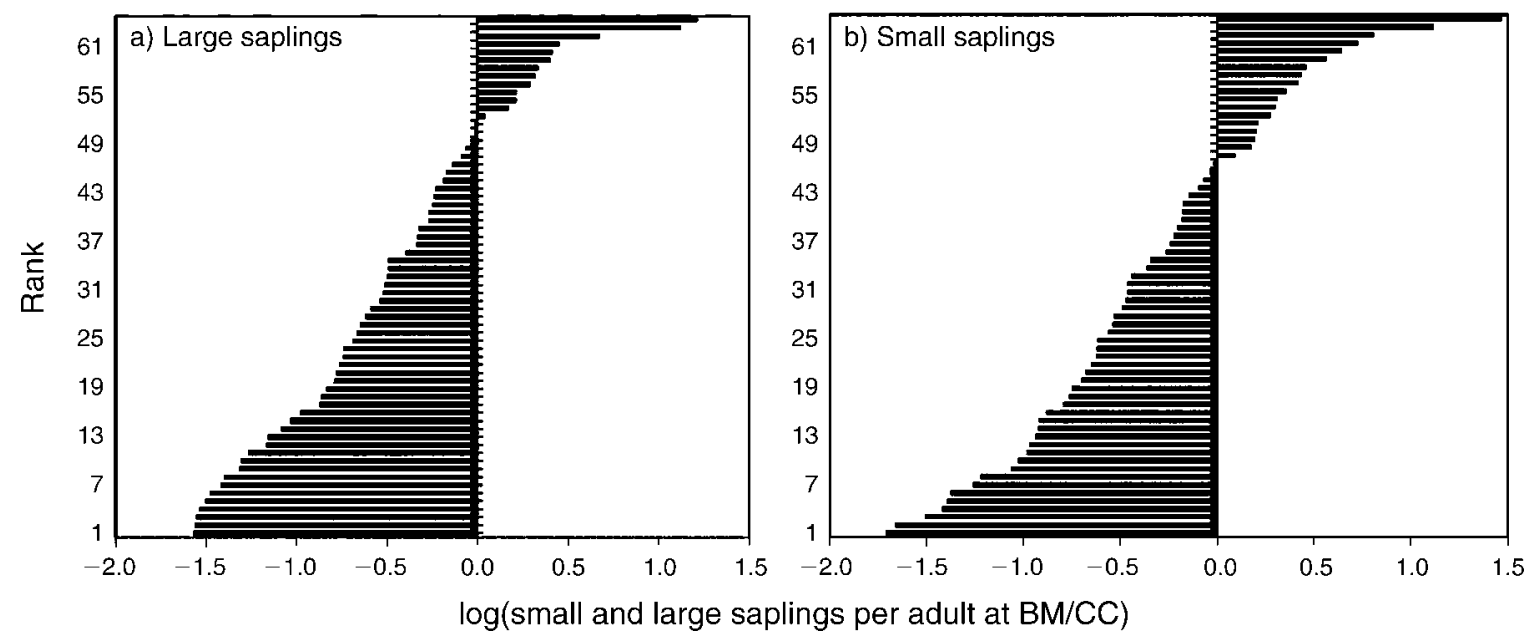

FIG. 3. "Winners" and "Losers" at Boca Manu as represented by the ratio $\log \left(\left[\right.\right.$ saplings $_{\text {adj }} /$ adult $\left._{\mathrm{BM}} /[\text { saplings/adult }]_{\mathrm{CC}}\right)$, shown for (a) large saplings and (b) small saplings. Numbers of saplings at Boca Manu (BM) are adjusted to the same totals as at Cocha Cashu Biological Station (CC) so that the null hypothesis of equal numbers of saplings per adult at both sites is represented by the vertical line in the center of each frame (expected ratio $=1.0, \log$ expected ratio $=0$ ). Ratios $>0$ represent species in which small saplings are relatively more abundant at $\mathrm{BM}$ than at $\mathrm{CC}$; ratios $<0$ represent species in which small saplings are relatively less abundant at $\mathrm{BM}$ than at $\mathrm{CC}$.

in the number of saplings per adult with respect to the reference site (CC). We thus compared sapling to adult ratios in 65 tree species for which at least minimal data were available. After adjusting for the difference in sapling density between the two plots, the expected ratio for all species was assumed to be 1.0 (null hypothesis, see Methods). However, the observed ratios [(sapling adj $_{\text {/ }}$ adult $)_{\mathrm{BM}} /(\text { sapling/adult })_{\mathrm{CC}}$, deviated widely from unity, ranging from 16.3 to 0.02 for large saplings (Fig. 3a) and 29.2 to 0.01 for small saplings (Fig. 3b). Of the 65 species in the small-sapling comparison, $18(28 \%)$ had values of $>1.0$, suggesting population increases and 47 (72\%) had values of $<1.0$, suggesting decreases. Only 19 species (29\%) had ratios that fell within a twofold range $(0.5-$ 2.0) of the expected value of unity. The results for large saplings were similar (Fig. 3a).

\section{Prediction 4: seed size}

Decimation or complete loss of the largest vertebrate dispersers at BM might be expected to selectively hinder the recruitment of large-seeded trees (Prediction 4). We examined this prediction in two ways. First, we tested the hypothesis that deviations of sapling to adult ratios from the expected value of parity would correlate with seed dry mass. The hypothesis was supported by a significant correlation between the magnitude of deviations from the expected value of 1.0 with seed mass for the 56 species for which we had both types of data (Spearman's rho $=0.30, P=0.02$ ). Second, we compared the 10 species of small saplings with the most positive ratios (presumed to be increasing at $\mathrm{BM}$ ) with the 10 having the most negative ratios (presumed to be decreasing) with respect to dry seed mass. Again, as predicted, the mean dry seed mass of the species with the
10 most negative ratios was six times greater than that of species with the 10 most positive ratios $(1.65 \mathrm{~g}$ vs. $0.27 \mathrm{~g}$; $P=0.005$ by $t$ test).

\section{Prediction 5: aggregation of saplings near adults}

Under reduced dispersal, larger fractions of seed crops will fall near or under parent trees, potentially leading to increased recruitment near adults. However, this naïve expectation conflicts with Prediction 5, derived from the $\mathrm{J}-\mathrm{C}$ model for the case being considered, that of a lowered dispersal curve and relatively unaltered escape curve. Under these assumptions, the $\mathrm{J}-\mathrm{C}$ model predicts reduced overall recruitment of saplings with little or no change in their spatial distribution (cf. Introduction: Predictions).

To investigate the spatial distribution of saplings, we computed the distance of each sapling to every conspecific adult at both sites using the Pythagorean theorem. The distance to the nearest conspecific adult for each sapling was designated as $D_{\min }$. $D_{\min }$ values for the saplings of 65 species meeting minimum data requirements (see Methods) were averaged to yield a mean for each species, designated as $D_{\text {obs }}$. Values of $D_{\text {obs }}$ were converted to logs and then regressed against the log of the density of conspecific adults for the small saplings at both sites (Fig. 4a, b). In addition, we used Eq. 1 to compute the mean sapling-to-nearest-adult distances, $D_{\text {exp }}$, that would be expected if saplings were randomly distributed with respect to adults. Values of $\log D_{\exp }$ are shown in Fig. 4a, b in the form of calculated regression lines overlaid on the regressions of $\log D_{\text {obs }}$ against the $\log$ of the density of conspecific adults. In neither case do the slopes of $\log D_{\text {obs }}$ differ significantly from those of $\log D_{\text {exp }}$, indicating, in general, that saplings are 

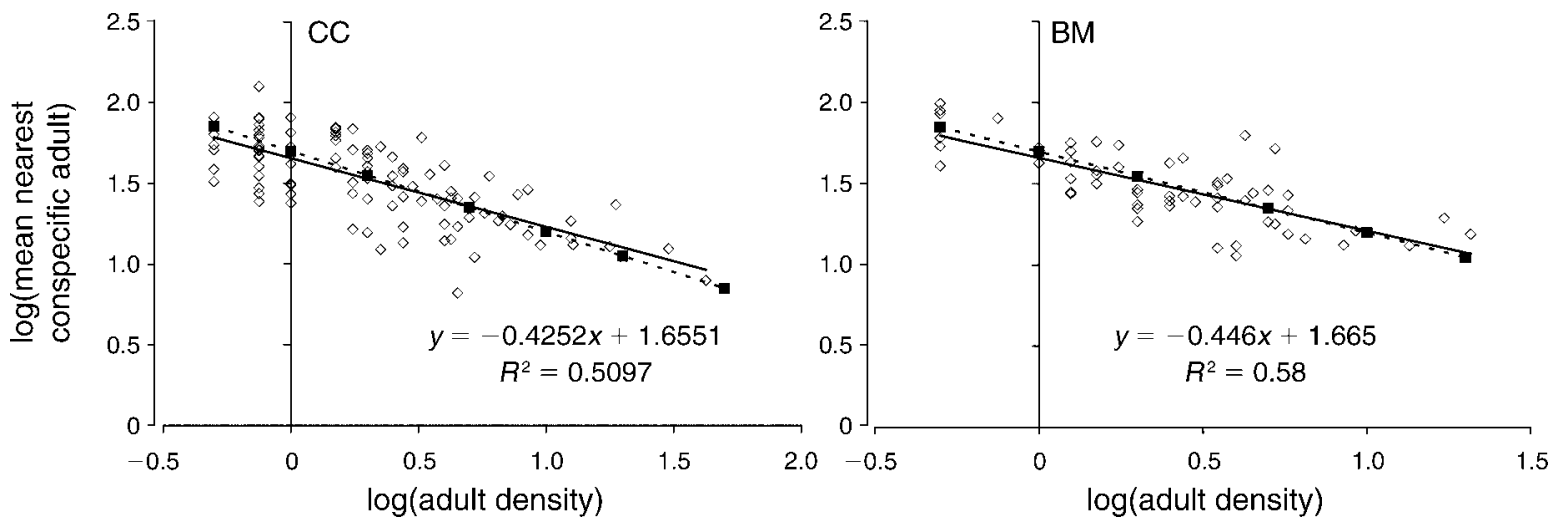

FIG. 4. Linear regression of log-transformed mean distances of small saplings from the nearest conspecific adult vs. logtransformed values of adult density (no./ha) at Cocha Cashu Biological Station (CC; left) and Boca Manu (BM; right). Each point represents the mean value for a species (open diamonds, solid regression line). Superimposed on the regression plots in each frame is a calculated line (solid squares, dotted line) that gives the expected nearest neighbor distance of randomly arrayed points in a plane as a function of the density of points. Neither regression line differs significantly from the calculated line, indicating that, on average, saplings are randomly distributed with respect to adults (i.e., there is no tendency of saplings to clump near adults).

randomly distributed with respect to conspecific adults at both sites. A higher $r^{2}$ value (0.58) for small saplings at $\mathrm{BM}$ than at $\mathrm{CC}(0.51)$ argues against any tendency for saplings to cluster closer to adults at BM.

\section{DiscusSION}

We compared tree stands at two sites in the Rio Manu floodplain in southeastern Peru: Boca Manu and Cocha Cashu Biological Station. The forest at Boca Manu (BM) has been subject to intense commercial hunting for $>30$ years and proved deficient in large vertebrate seed dispersers, seed predators, and herbivores. Cocha Cashu Biological Station (CC) is deep within the Manu National Park and supports an intact fauna. Representative 4-ha plots at the two locations were nearly identical in basal area and species richness. The two plots shared $70 \%$ of their species, an exceptionally high fraction that reflects the oligarchic organization of forests in western Amazonia (Pitman et al. 2001). Given that $\sim 700$ tree species occur in Rio Manu floodplain forests, most of the $30 \%$ of species in each stand that were not shared were uncommon species that merely failed to appear in a sample of $\sim 2300$ individuals.

Against a background of uniformity in the structure and composition of the respective tree communities, the large vertebrate communities of the two sites were strikingly divergent. Large arboreal mammals and birds and large terrestrial mammals were reduced by $80-100 \%$ at BM. The decimated species included spider and howler monkeys, capuchins, white-lipped peccaries, guans, and curassows. Spider monkeys are the most important seed dispersers in the fauna and white-lipped peccaries are major seed predators (Kiltie 1981, Janson and Emmons 1990, Terborgh et al. 1990, Andresen 1999, Russo 2003, Silman et al. 2003). Nocturnal arboreal mammals and small $(<1 \mathrm{~kg})$ diurnal birds and mammals were relatively unaffected, leaving intact the forest's seed disperser and seed predator functions at the low end of the size scale. The selective loss of large species is characteristic of forests exposed to hunting in Amazonia generally as well as elsewhere in the tropics (O'Brien and Kinnaird 2000, Peres 2000, Fa et al. 2002).

Using the two stands as experiment (BM) and control (CC), we tested five hypotheses based on the JanzenConnell (J-C) hypothesis. The hypotheses were that the "empty" forest (depleted of large birds and mammals) should (1) support reduced densities of saplings, (2) contain a higher proportion of stems dispersed by abiotic means, (3) show evidence of ongoing shifts in species composition, (4) show reduced recruitment of large-seeded species, and (5) show no change in the spatial dispersion of saplings with respect to conspecific adults. Our results supported all five hypotheses.

Densities of large $(\geq 1 \mathrm{~cm} \mathrm{dbh},<10 \mathrm{~cm} \mathrm{dbh})$ and small ( $\geq 1 \mathrm{~m}$ tall, $<1 \mathrm{~cm} \mathrm{dbh}$ ) saplings at BM were only $60 \%$ and $52 \%$ of their respective values at CC. The possibility that the difference was due to a greater prevalence of light gaps at CC was discounted in a comparison of canopy cover in the two plots that revealed no discernible difference.

As predicted, sapling cohorts at BM contained higher proportions of species dispersed by wind and reduced proportions of species dispersed by animals, especially large primates. Classifying species by dispersal guild inevitably requires judgment calls because many zoochorous trees are dispersed by a wide variety of animals that may include both large and small members of diverse taxa (Gautier-Hion et al. 1985, Poulsen et al. 2002, Russo 2003). Thus, attempts to distinguish the roles of large vs. small primates, for example, are bound to be imprecise. The fact that sapling densities of zoochorous tree species were generally reduced at BM suggests broad overlap in the functioning of dispersal guilds as we defined them.

We evaluated the prediction of compositional change using sapling to adult ratios under the assumption that 
ratios of 1.0 would indicate population stability. Only a minor fraction $(29 \%)$ of the species of small saplings at $\mathrm{BM}$ had ratios that fell even within a factor of $2(0.5-$ $2.0)$ of the null expectation. Overall, the ratios of $28 \%$ of the species at $\mathrm{BM}$ were $>1.0$, suggesting increased recruitment vis à vis $\mathrm{CC}$, whereas those of $72 \%$ were $<1.0$, suggesting reduced recruitment. Interpreted at face value, these data suggest that the forest at BM is undergoing a major shift in species composition.

Although the evidence at hand for compositional change seems compelling, it is not possible to predict the future with any confidence from data representing a single slice in time. Repeated censuses will be required to measure rates of recruitment, survivorship, and mortality that can be used to parameterize predictive models. Moreover, any currently detectable signal of compositional change in the BM sapling cohorts is likely to be diluted by the presence of long-suppressed saplings that germinated prior to the defaunation of the early 1970s. Beyond these caveats, little is known about the extent of site-to-site variation in sapling to adult ratios that may occur in the absence of distortions in the vertebrate community. Some of the deviations from unity seen in Fig. 3 are probably within the "normal" range and thus nonsignificant, whereas others certainly are significant because the deviations span a range of more than three orders of magnitude. Thus, our results should be taken as preliminary and suggestive rather than as a definitive assessment of compositional change in an "empty" forest.

Prediction 4 was that the selective decimation of largebodied dispersers at BM should particularly disadvantage large-seeded tree species. The prediction was supported by the finding that sapling/adult ratios were significantly lower among large-seeded species than among small-seeded species. Further, large-seeded species were disproportionately represented among those showing the greatest negative discrepancies in sapling densities at BM. These results affirm the often expressed opinion that large-seeded species are especially vulnerable to the disruption of biotic interactions (Forget et al. 1999, Wright et al. 2000, Jansen et al. 2002, Fragoso et al. 2003).

The final prediction was that of no change at BM in the spatial distribution of saplings with respect to adults. The prediction was based on the argument that there is much more functional redundancy and opportunity for compensation with respect to the escape curve than there is in the dispersal function, especially for species bearing large-seeded fruits. If, contrary to our assumption, a reduction in the density of large seed predators (agoutis and peccaries) at BM had resulted in a lifting of the escape curve for affected species, a shift in recruitment toward adults would be predicted. Yet, no such tendency was observed, supporting our prediction. For a shift in recruitment toward adults to occur, undispersed seeds would have to experience greater success (i.e., via increased escape). Independent evidence suggests that undispersed seeds have very low success.
Conservative estimates suggested that $>95 \%$ of saplings of common species at CC arose from dispersed seeds and $>98 \%$ of saplings of less common species, implying that the vast majority of undispersed seeds are doomed to fail, as anticipated by Janzen and Connell (Terborgh et al. 2002, Terborgh and Nuñez-Iturri 2006).

Undispersed seeds are susceptible to attack from a multiplicity of agents acting in a distance-dependent fashion. Thus, the escape curve may be relatively resilient to distortions in the local vertebrate fauna. Moreover, there is some evidence that small vertebrate and invertebrate seed predators may show compensatory increases in abundance where large vertebrate seed predators are scarce or absent (Asquith et al. 1997, Wright et al. 2000, Wyatt and Silman 2004). Thus, the hunting of large vertebrates in Rio Manu floodplain forest appears to result primarily in the lowering and/or truncation of seed shadows while leaving the escape process relatively intact.

The massive compositional change that appears to be underway in the forest at Boca Manu brings into question the "sustainable use" of game resources in tropical forests (Robinson et al. 1999). Our results suggest that the best, and perhaps only, way to prevent compositional change and probable loss of diversity in tropical tree communities is to leave the animal community intact. Yet, already the intact faunas needed to perpetuate the plant community of tropical forests have been widely disrupted (Redford 1992, Peres and Dolman 2000, Fa et al. 2002). Just a few hunters per $\mathrm{km}^{2}$ can decimate populations of large-bodied vertebrates (Peres and Dolman 2000). Peres and Lake (2003) estimate that only a minor fraction of the vast roadless wilderness contained within the Brazilian Amazon is inaccessible to hunters. With the implementation of existing development plans, this figure is destined to shrink even further (Laurance et al. 2005).

Compositional change in response to altered vertebrate community structure is a particularly insidious threat to biodiversity because it requires painstaking studies to detect. It would be unsettling enough if the changes were merely random, but the evidence presented here indicates that loss of dispersal function leads to directional change, specifically, the substitution of a small number of species dispersed abiotically and by small birds and mammals for a rich assemblage of species dispersed by large birds and mammals. Substitution of abiotic for biotic dispersal is likely to generate negative feedbacks on both the animal and plant communities. Forests depleted in large-seeded tree species will offer fewer resources for large vertebrates. Even if hunting could be controlled, recovery of the original tree community is likely to be retarded in the presence of reduced populations of large vertebrates. Moreover, reduced animal biomass will slow rates of nutrient recycling via urine and feces and result in decreased productivity, a condition that will feed back to slow the recovery of the vertebrate community (Feeley 
and Terborgh 2005). The bottom-line message is one that should be heeded by conservationists and foresters alike: a tropical forest is a complex interacting system of plants and animals and the one cannot live without the other.

\section{ACKNOWLEDGMENTS}

We thank Manuel Sanchez, Martina Chavez de Sanchez, Erasmo Guerra, Jorge Valle, and Santos Valle for field assistance at Boca Manu and others too numerous to name for help with the tree and sapling plots at CC. Financial support was provided by the Andrew Mellon Foundation. G. NuñezIturri gratefully acknowledges support from the Canon National Parks Science Scholars Program. We thank the reviewers for many constructive suggestions.

\section{Literature Cited}

Adler, G. H. 1995. Fruit and seed exploitation by Central American spiny rats, Proechimys semispinosus. Studies on Neotropical Fauna and Environment 30:237-244.

Andresen, E. 1999. Seed dispersal by monkeys and the fate of dispersed seeds in a Peruvian rain forest. Biotropica 31:145158.

Andresen, E., and S. G. W. Laurance. 2007. Possible indirect effects of mammal hunting on dung beetle assemblages in Panama. Biotropica 39:141-146.

Asquith, N. M., and M. Mejia-Chang. 2005. Mammals, edge effects, and the loss of tropical forest diversity. Ecology 86: 379-390.

Asquith, N. M., J. Terborgh, A. E. Arnold, and C. M. Riveros. 1999. The fruits the agouti ate: Hymenaea courbaril seed fate when its disperser is absent. Journal of Tropical Ecology 15: 229-235.

Asquith, N. M., S. J. Wright, and M. J. Clauss. 1997. Does mammal community composition control recruitment in neotropical forests? Evidence from Panama. Ecology 78: 941-946.

Condit, R., S. P. Hubbell, and R. B. Foster. 1992. Recruitment near conspecific adults and the maintenance of tree and shrub diversity in a neotropical forest. American Naturalist 140: 261-286.

Condit, R., R. Sukumar, S. P. Hubbell, and R. B. Foster. 1998. Predicting population trends from size distributions: a direct test in a tropical tree community. American Naturalist 152: 495-509.

Connell, J. H. 1971. On the role of natural enemies in preventing competitive exclusion in some marine animals and in rain forest trees. Pages 298-310 in P. J. den Boer and G. R. Gradwell, editors. Dynamics of populations. Centre for Agricultural Publications and Documentation, Wageningen, The Netherlands.

Cordeiro, N. J., and H. F. Howe. 2001. Low recruitment of trees dispersed by animals in African forest fragments. Conservation Biology 15:1733-1741.

Dirzo, R., and A. Miranda. 1991. Altered patterns of herbivory and diversity in the forest understory: a case study of the possible consequences of contemporary defaunation. Pages 273-287 in P. W. Price, P. W. Lewinsohn, G. W. Fernandes, and W. W. Benson, editors. Plant-animal interactions: evolutionary ecology in tropical and temperate regions. John Wiley, New York, New York, USA.

Emmons, L. H. 1989. Tropical rain forests: why they have so many species and how we may lose this biodiversity without cutting a single tree. Orion 8:8-14.

Fa, J. E., C. A. Peres, and J. Meeuwig. 2002. Bushmeat exploitation in tropical forests: an intercontinental comparison. Conservation Biology 16:232-237.

Feeley, K. J., and J. W. Terborgh. 2005. The effects of herbivore density on soil nutrients and tree growth in tropical forest fragments. Ecology 86:116-124.
Forget, P.-M., F. Mercier, and F. Collinet. 1999. Spatial patterns of two rodent-dispersed rain forest trees Carapa procera (Meliaceae) and Vouacapoua americana (Caesalpiniaceae) at Paracou, French Guiana. Journal of Tropical Ecology 15:301-313.

Foster, S. A., and C. H. Janson. 1985. The relationship between seed size and establishment conditions in tropical woody plants. Ecology 66:773-780.

Fragoso, M. V., K. M. Silvius, and J. A. Correa. 2003. Longdistance seed dispersal by tapirs increases seed survival and aggregates tropical trees. Ecology 84:1998-2006.

Gautier-Hion, A., et al. 1985. Fruit characters as a basis of fruit choice and seed dispersal in a tropical forest vertebrate community. Oecologia 65:324-337.

Gentry, A. H. 1993. A field guide to the families and genera of woody plants of northwest South America (Colombia, Ecuador, Peru) with supplementary notes on herbaceous taxa. Conservation International, Washington, D.C., USA.

Howe, H. F., E. W. Schupp, and L. C. Westley. 1985. Early consequences of seed dispersal for a neotropical tree (Virola surinamensis). Ecology 66:781-791.

Hubbell, S. H. 1980. Seed predation and the coexistence of tree species in tropical forests. Oikos 35:214-229.

Hubbell, S. H. 2004. Two decades of research on the BCI forest dynamics plot. Pages 8-30 in E. C. Losos and E. G. Leigh, Jr., editors. Tropical forest diversity and dynamism: findings from a large-scale plot network. University of Chicago Press, Chicago, Illinois, USA.

Hubbell, S. P., and R. B. Foster. 1990. The fate of juvenile trees in a neotropical forest: implications for the natural maintenance of tropical tree diversity. Pages 317-341 in K. S. Bawa and M. Hadley, editors. Reproductive ecology of tropical plants. UNESCO, Paris, France.

Hubbell, S. P., R. B. Foster, S. T. O'Brien, K. E. Harms, R. Condit, B. Wechsler, S. J. Wright, and S. Loo de Lao. 1999. Light-gap disturbances, recruitment limitation, and tree diversity in a Neotropical forest. Science 283:554-557.

Jansen, P., M. Bartholomeus, F. Bongers, J. A. Elzinga, J. den Ouden, and S. E. van Wieren. 2002. The role of seed size in dispersal by a scatter-hoarding rodent. Pages 209-225 in D. J. Levey, W. R. Silva, and M. Galetti, editors. Seed dispersal and frugivory: ecology, evolution and conservation. CABI Publishing, Wallingford, UK.

Janson, C. H., and L. H. Emmons. 1990. Ecological structure of the nonflying mammal community at Cocha Cashu Biological Station, Manu National Park, Perú. Pages 314-338 in A. H. Gentry, Jr., editor. Four Neotropical rainforests. Yale University Press, New Haven, Connecticut, USA.

Janzen, D. H. 1970. Herbivores and the number of tree species in tropical forests. American Naturalist 104:501-528.

Kiltie, R. A. 1981. Stomach contents of rain forest peccaries (Tayassu tajacu and T. pecari). Biotropica 13:234-236.

Laurance, W. F., M. A. Cochrane, S. Bergen, P. M. Fearnside, P. Delamonica, C. Barber, S. D'Angelo, and T. Fernandes. 2005. The future of the Brazilian Amazon. Science 291:438 439.

O'Brien, T. G., and M. F. Kinnaird. 2000. Differential vulnerability of large birds and mammals to hunting in north Sulawesi, Indonesia, and the outlook for the future. Pages 199-230 in J. G. Robinson and E. L. Bennett, editors. Hunting for sustainability in tropical forests. Columbia University Press, New York, New York, USA.

Peres, C. A. 1999. General guidelines for standardizing linetransect surveys of tropical forest primates. Neotropical Primates 7:11-16.

Peres, C. A. 2000. Effects of subsistence hunting on vertebrate community structure in Amazonian forests. Conservation Biology 14:240-253.

Peres, C. A., and P. M. Dolman. 2000. Density compensation in neotropical primate communities: evidence from 56 hunted 
and nonhunted Amazonian forests of varying productivity Oecologia 122:175-189.

Peres, C. A., and I. R. Lake. 2003. Extent of nontimber resource extraction in tropical forests: accessibility to game vertebrates by hunters in the Amazon basin. Conservation Biology 17:521-535.

Peres, C. A., and E. Palacios. 2007. Basin-wide effects of game harvest on vertebrate population densities in Amazonian forests: implications for animal-mediated seed dispersal. Biotropica 39:304-315.

Peres, C. A., and M. van Roosmalen. 2002. Patterns of primate frugivory in Amazonia and the Guianan shield: implications to the demography of large-seeded plants in overhunted tropical forests. Pages 407-423 in D. J. Levey, W. R. Silva, and M. Galetti, editors. Seed dispersal and frugivory: ecology, evolution, and conservation. CABI Publishing, Wallingford, UK.

Pitman, N. C. A., J. Terborgh, M. R. Silman, V. P. Nuñez, D. A. Neill, C. E. Cerón, W. A. Palacios, and M. Aulestia. 2001. Dominance and distribution of tree species in upper Amazonian terra firme forests. Ecology 82:2101-2117.

Poulsen, J. R., C. J. Clark, E. F. Connor, and T. B. Smith. 2002. Differential resource use by primates and hornbills: implications for seed dispersal. Ecology 83:228-240.

Redford, K. H. 1992. The empty forest. Bioscience 42:412-422.

Robinson, J. G., K. H. Redford, and E. L. Bennett. 1999. Wildlife harvest in logged tropical forests. Science 284:595596.

Romo, M. 1997. Seasonal variation in fruit consumption and seed dispersal by canopy bats (Artibeus spp.) in a lowland forest in Peru. Vida Silvestre Neotropical 5:110-119.

Russo, S. E. 2003. Responses of dispersal agents to tree and fruit traits in Virola calophylla (Myristacaceae): implications for selection. Oecologia 136:80-87.

Silman, M. R., J. W. Terborgh, and R. A. Kiltie. 2003. Population regulation of a dominant rain forest tree by a major seed predator. Ecology 84:431-438.

Stevenson, P. R., M. J. Quiñones, and M. C. Castellanos. 2000. Guía de frutos de los bosques del río Duda La Macarena, Colombia. Netherlands Committee for IUCN, Tropical Rainforest Programme, Amsterdam, The Netherlands.

Terborgh, J. 1983. Five New World primates: a study in comparative ecology. Princeton University Press, Princeton, New Jersey, USA.

Terborgh, J., R. B. Foster, and P. Nuñez V. 1996. Tropical tree communities: a test of the nonequilibrium hypothesis. Ecology 77:561-567.
Terborgh, J., and A. H. Gentry. 1990. Composition and dynamics of the Cocha Cashu "mature" floodplain forest. Pages 542-564 in A. H. Gentry, editor. Four neotropical rainforests. Yale University Press, New Haven, Connecticut, USA.

Terborgh, J., and G. Nuñez-Iturri. 2006. Disperser-free tropical forests await an unhappy fate. Pages 241-252 in W. F. Laurance and C. A. Peres, editors. Emerging threats to tropical forests. University of Chicago Press, Chicago, Illinois, USA.

Terborgh, J., N. Pitman, M. Silman, H. Schichter, and P. Nuñez V. 2002. Maintenance of tree diversity in tropical forests. Pages 1-17 in D. J. Levey, W. R. Silva, and M. Galetti, editors. Seed dispersal and frugivory: ecology, evolution and conservation. CAB International, Wallingford, UK.

Terborgh, J., S. K. Robinson, T. A. Parker III, C. A. Munn, and N. Pierpont. 1990. Structure and organization of an Amazonian forest bird community. Ecological Monographs 60:213-238.

van Roosmalen, M. G. M. 1985. Fruits of the Guianan flora. Institute of Systematic Botany, Utrecht, The Netherlands.

Wang, B. C., M. T. Leong, T. B. Smith, and V. L. Sork. 2006. Ecological repercussions of extirpating mammals: reduced seed removal and dispersal of the Afrotropical tree, Antrocaryon klaineanum (Anacardiaceae). Biotropica 38: 792-793.

Welden, C. W., S. W. Hewett, S. P. Hubbell, and R. B. Foster. 1991. Sapling survival, growth, and recruitment: relationship to canopy height in a neotropical forest. Ecology 72:35-50.

Wright, S. J. 2003. The myriad effects of hunting for vertebrates and plants in tropical forests. Perspectives in Plant Ecology, Evolution and Systematics 6:73-86.

Wright, S. J., A. Hernandez, and R. Condit. 2007a. The bushmeat harvest alters seedling banks by favoring lianas, large seeds, and seeds dispersed by bats, birds, and wind. Biotropica 39:363-371.

Wright, S. J., K. E. Stoner, N. Beckman, R. T. Corlett, R. Dirzo, H. C. Muller-Landau, G. Nunez-Iturri, C. A. Peres, and B. C. Wang. 2007b. The plight of large animals in tropical forests and the consequences for plant regeneration. Biotropica 39:289-291.

Wright, S. J., H. Zeballos, I. Dominguez, M. M. Gallard, M. Moreno, and R. Ibañez. 2000. Poachers alter mammal abundance, seed dispersal, and seed predation in a Neotropical forest. Conservation Biology 14:227-239.

Wyatt, J. L., and M. R. Silman. 2004. Distance-dependence in two Amazonian palms: effects of spatial and temporal variation in seed predator communities. Oecologia 140:26-35. 